Open Access

\title{
Job creation and improved consumer health through commercialisation of tiger nut yoghurt: a willingness to pay analysis
}

Camillus Abawiera Wongnaa ${ }^{1 *} \mathbb{D}$, Faizal Adams ${ }^{1}$, Richard Kwasi Bannor², Dadson Awunyo-Vitor ${ }^{1}$, Isaac Mahama', Bismark Afoakwa Osei ${ }^{1}$, Yaw Owusu-Ansah ${ }^{1}$ and Angelina Ackon ${ }^{1}$

* Correspondence: wongnaaa@ yahoo.com

${ }^{1}$ Department of Agricultural Economics, Agribusiness and Extension, Kwame Nkrumah University of Science and Technology, Private Mail Bag, University Post Office, Kumasi, Ghana

Full list of author information is available at the end of the article

\begin{abstract}
The study assessed consumers' perception and willingness to pay for tiger nut yoghurt developed by Sanful (Pak J Nutr 6:755-758, 2009) in Ghana. It used cross-sectional data collected from 315 yoghurt consumers from five (5) communities in the Kumasi metropolis. Descriptive statistics, 3-point Likert scale, perception index and the tobit regression model were the analytical tools employed. The results showed that while consumers considered nutritional benefits as the most important attribute, they considered appearance as the least. The overall mean perception index was 0.67, indicating that consumers had a positive perception for tiger nut yoghurt. Even though the price of $500 \mathrm{ml}$ of 'normal' yoghurt was Ghל2.50 (US\$0.57), consumers were willing to pay Gh\$3.50 (US\$0.79) for the same volume. Finally, the results revealed that, consumers' willingness to pay (WTP) for tiger nut yoghurt was influenced by age, sex, educational level, household size, monthly income and price of the product. The study concludes that Sanful's tiger nut yoghurt has bright market prospects in the Kumasi metropolis and similar urban settings. Entrepreneurs, the unemployed and investors are therefore encouraged to consider a business in tiger nut yoghurt production even though there is also the need for a profitability analysis of tiger nut yoghurt production. In addition, there is the need to increase awareness and education on the nutritional and health benefits of tiger nut since education has a positive influence on consumers' willingness to pay for the product.
\end{abstract}

Keywords: Attributes, Perception, Willingness to pay, Tiger nut yoghurt

\section{Introduction}

Heightening interest in safer and healthy food products are prompting governments, health practitioners, and consumers particularly in Sub-Saharan Africa to more carefully select nutritious and healthy indigenous food resources such as "tiger nuts" for processing and consumption which currently are consumed raw and unwholesome (Mordi et al. 2006). Improved consumption of processed tiger nut (Cyperus esculentus) will not only provide remedies to major nutritional and health problems of society but could also serve as a potential source of improve incomes to farmers and other value chain actors such as processors and marketers. Health problems will be solved because a study by Adebajo (1993) has reported the existence of aflatoxins at toxicologically unsafe levels on tiger nuts sold on streets while Bankole and Adebanjo (2003) also

(C) The Author(s). 2019 Open Access This article is distributed under the terms of the Creative Commons Attribution 4.0 International License (http://creativecommons.org/licenses/by/4.0/), which permits unrestricted use, distribution, and reproduction in any medium, provided you give appropriate credit to the original author(s) and the source, provide a link to the Creative Commons license, and indicate if changes were made. 
observed the presence of mycotoxins on the nuts. In fact, majority, representing $70 \%$ of tiger nuts produced in the country are consumed unprocessed with a lot of contaminations such as stones, animal droppings and some food-borne diseases such as aflatoxins and mycotoxins (Adebajo 1993; Bankole and Adebanjo 2003; Mordi et al. 2006). A number of factors, such as direct contact of nuts with the soil, unhygienic handling, and the use of contaminated water for irrigation, could have accounted for the contamination observed. Meanwhile, the small amount that are processed into porridges (locally known as "atadwe" milk) are carried out under rudimentary technologies without adherence to strict food safety compliances (Tetteh and Ofori 1998).

Despite the dietary, health and economic promise of tiger nut in Ghana, the production and utilisation of the nut has received little attention especially from government. Attempts to commercialise the product are left within the domain of rural poor farmers and small-scale traders. A Ghanaian knowledge about tiger nut and its related product is scanty with majority acknowledging the nuts for its aphrodisiac trait (Plants 1988). Sanful (2009), therefore, in a nutritional and sensory analysis to create awareness and promote the consumption of processed tiger nut products, suggests that tiger nut milk (yoghurt) offers a feasible, hygienic and nutritious alternative yoghurt as oppose to cow milk in Ghana. The fundamental question that arises from the nutritional and sensory analysis is whether consumers will be willing to pay for such tiger nut yoghurt given consumers' affinity for the nuts, the premium price to be paid and the fact that tiger nut yoghurt is a new product on the market.

While the study by Sanful (2009) provides a breakthrough for value addition of tiger nut, no information is available on consumer's perception and willingness to pay (WTP) for such locally produced yoghurt at premium prices and the importance of this information for farmers, processors, governments and private individuals, making the need for such studies to be conducted. Meanwhile, knowledge about consumers' perception and willingness to pay on a product plays a critical role in numerous areas of marketing management like price choices, creation of high valued products and exploitation of new market segments opportunities. Hence the objective of this study was to assess consumers' perception and willingness to pay a premium for tiger nut yoghurt when introduced on the market. Specifically, the study sought to ascertain the perception of consumers about the health and nutritional benefits of tiger nut, determine consumers' willingness to pay (WTP) a premium for tiger-nut yoghurt and finally, determine the factors that affect consumers' willingness to pay a premium for tiger nut yoghurt. That is, there is one thing producing a new product of value and one thing commercializing it. A valuable product may be produced but if it does not reach the target consumers, then the purpose of the production is not achieved. The study provides information about how the valuable product produced by Sanful (2009), can be promoted by existing and potential entrepreneurs for profit.

The paper is structured into five sections. The next section reviews literature relevant for the study which is followed by the research methodology employed in the study. The study results and discussions based on the data analyses are fully detailed. Conclusions drawn are then presented, followed by recommendations.

\section{Literature review}

Tiger nut is a perennial grass-like plant with spheroid tubers, pale yellow cream kernel surrounded by a fibrous sheath, which grows to about $90 \mathrm{~cm}(3.0 \mathrm{ft}$.) tall, with solitary 
stems growing from a tuber. It is also known as yellow nut sedge, earth or ground almonds, "souchet" in French, "ermandeln" in German and "chufa" in Spanish (TTSL 2005). In many countries, Cyperus esculentus is considered a weed (Adejuyitan 2011; Ukwuru and Ogbodo 2011). In Ghana, it grows in the wild, along rivers and are cultivated on a small scale by rural farmers mostly in the Eastern region of the country and parts of central region especially Awutu Obrakyire, Okuse Nkwanta and Bawjiase areas. The planting season in Ghana is between April and May and is mostly irrigated every week. Tubers develop about 6-8 weeks after seedling emergence and grow quickly during July and August. Maturity is around 90-110 days. The average yield ranges between 10 and 19 t/ha (Pascual-Seva et al. 2016). The nuts are locally called "aya" in Hausa; "atadwe" in Twi and "atangbe" in Ga in the Ghanaian parlance. Tiger nuts are edible, sweet, nutty, flavoured tubers which contain protein, carbohydrate, sugars and lots of oil and fibre. Despite its name and its chemical composition which comprises characteristics of both tubers and nuts, tiger nut is a tuber (Pascual et al. 2000). It has been reported to be a "health" food since its consumption can help prevent heart diseases and thrombosis and is said to activate blood circulation and reduce the risk of colon cancer. The nut or tuber, when processed into milk, comes with varying nutritional and medicinal values similar to chemical compositions contained in nuts and tubers (Kampman et al. 1994; Arafat et al. 2009). Also, according to Mason (2008), tiger nut juice has been recognized for its additional health benefits as they are high in fibre, protein and natural sugars. The milk contains almost twice the quantity of starch as potato or sweet potato tubers (Arafat et al. 2009). It has also been found to possess good therapeutic properties since its consumption is found to be positively related to healthier cholesterol levels (Moore 2004).

Besides processing tiger nut into milk, a variety of other food products are derived from it through various food processing techniques to modify its appearance, develop its natural flavour, stimulate the digestive juices, add variety to the menu, make it easily digestible, destroy harmful microorganisms, improve its nutritional quality and prevent decomposition (Plants 1988). Studies have shown that tiger nut can be used as an alternative source of fuel which is cheaper, safer, and more environmentally friendly in comparison with widely used burning fuels. Since tiger nut contains $20-36 \%$ oil, it has also been suggested as a potential oil crop for the production of biodiesel (Zhang 1996).

The current state of tiger nut and its related products consumption poses a serious threat to public health in Ghana. Consequently, the demand for such a high health risk tiger nuts is likely to be low irrespective of its nutritional and health benefits as more people are becoming dietary health conscious (Rheinländer et al. 2008). With a decrease in demand for tiger nuts, farmers will be less motivated to expand the scale of their production as no farmer will put in extra effort to produce tiger nuts if the markets are not efficient (Bannor and Dhaka 2015). This will inevitably cause the under-exploitation of the economic benefits of tiger nut production and marketing. Therefore, finding an alternative form in which the nutritional and health benefits of tiger nuts could be exploited with high demand will encourage farmers to go into more intensive production. This will reduce the rate of unemployment, especially in the production, processing and marketing areas. At the end, producers will be able to maximize their revenue and livelihood will be enhanced, making poverty eradicated and at the same time good health of consumers will be assured, making a strong case for meeting the 
first three Sustainable Development Goals (SDGs), viz. no poverty, zero hunger as well as good health and well-being. Added to this is the fact that tiger nut is currently an underutilised crop in Ghana since there is no significant commercial product from the nut (Tetteh and Ofori 1998; Shikhov et al. 2011; Adejuyitan 2011; Ukwuru and Ogbodo 2011). More so, research into the production, utilisation and marketing of tiger nut has been few and scanty (Shikhov et al. 2011) except the work of Sanful (2009) on the feasibility of producing healthy yoghurt from tiger nut milk prepared under strict laboratory regulations that will attract premium prices and is yet to be made readily available to consumers. Hence, it is not surprising that no effort has been made to commercialise the crop as compared to countries such as Spain where specialised regulatory authorities have been set up to foresee quality compliance (Tetteh and Ofori 1998; Yeboah 2014).

\section{Materials and methods}

\section{Study area}

The Kumasi metropolis in the Ashanti Region of Ghana, the second largest after Accra metropolis, the nation's capital, was purposively chosen for the study because of the presence of numerous yoghurt producers and consumers as well as its cosmopolitan nature and high population density. The metropolis has an approximate area of 254 $\mathrm{km}^{2}$ with approximately ten (10) kilometres in radius. It is located between latitudes $6^{0} 35^{\prime \prime}$ and $6^{\circ} 4^{\prime \prime} \mathrm{N}$ and longitudes $1^{0} 30^{\prime \prime}$ and $1^{0} 35^{\prime \prime}$ E. It has an elevation which ranges between 250 and $300 \mathrm{~m}$ above sea level. It shares boundaries with the Kwabre District to the north, Atwima-Kwanwoma and Atwima Mponua districts to the west, Ejisu-Juaben Municipal to the east and Bosomtwe District to the south. There are $103 \mathrm{commu}-$ nities in the Kumasi Metropolitan Assembly (KMA 2013). The metropolis is regarded as the most populous district in the Ashanti Region with a population of 2,035,064 and an annual growth rate of 4.8\% (GSS 2012). It has attracted such a large population partly because it is the regional capital and also the most commercialized center in the region. There are more males (50.2\%) than females (48.8\%) in the metropolis (KMA 2013). The metropolis' age structure is a youthful one. The average household size in the metropolis is 5.1 (KMA 2013).

Kumasi Metropolis is not only entirely urban. It is estimated that $48 \%, 46 \%$ and $6 \%$ of the metropolis are urban, peri-urban and rural respectively (KMA 2013). About 86\% of the active population in Kumasi is economically active (KMA 2013). The economic activities sustaining the livelihood of the residents in the metropolis can be categorized into Service, Industry and Agriculture. Agriculture in Kumasi consists of farming, aquaculture, horticulture and some animal rearing. Farming is limited to small scale staple crops production including maize, plantain, cocoyam, cassava and vegetables. With the occupational structure, $42 \%$ are engaged in sales and service occupations and $24.7 \%$ as production, transport and equipment operators (KMA 2013).

\section{Data collection}

The study used primary data collected from consumers who were mainly traders trading in various categories of commodities (e.g. agricultural produce commodities sellers, vendors, consumables, electrical installation materials, plumbing materials, small scale mobile phone accessories and small scale shoes sellers) as well as commercial drivers in 
the Kumasi metropolis using a structured questionnaire. Traders and commercial drivers were used because of the tedious work they do and because yoghurt is some kind of a readily available drink which is easily reached by these traders and drivers which is also able to boost their energy levels as soon as it is consumed. It employed the formula advanced by Yamane (1967) in the determination of the sample size. The formula is given as:

$$
n=\frac{N}{1+N e^{2}}
$$

where $n=$ desired sample size, $N=$ the finite size of the population, $e=$ maximum acceptable margin of error as determined by the researcher and $1=$ a theoretical or statistical constant. According to the 2010 Population and Housing Census, the population of Kumasi metropolis is 2,035,064 (GSS 2012). That is, assuming everybody in the metropolis is a potential consumer. Therefore, with a $5 \%$ margin of error, the sample size for the study was calculated as:

$$
n=\frac{2,035,064}{1+2,035,064(0.05)^{2}}=400
$$

The Multi-stage sampling technique was employed in the study. In stage one, five (5) communities were systematically selected from a list of communities in the Kumasi metropolis obtained from the Kumasi Metropolitan Assembly. This was done by selecting a community from the list at random as the starting point and then selecting every $k$ th community in the list or frame. " $k$ " was calculated by dividing the total number of communities in Kumasi Metropolis by the sample size (5). The selected communities were Asokwa, Atonsu, Manhyia, Subin and Bantama. In the second stage, 80 consumers who were either traders or commercial drivers were randomly selected from each of the five (5) communities with 10 consumers selected from each of agricultural produce commodities sellers, vendors, consumables dealers, electrical installation materials dealers, plumbing materials dealers, small scale mobile phone accessories dealers, small scale shoes sellers as well as commercial drivers. With 400 questionnaires that were sent out during the data collection, only 315 returned and therefore the researchers had no option than to use it as the sample size for the study.

The questionnaire was divided into four parts. Part one was designed to gather information on socio demographic information of the respondents such as age, sex, educational background of respondents, marital status, religious affiliation, ethnic affiliation of respondent, occupation of respondent, household size, average monthly income of respondent, and average monthly income of household. The second part elicited information on respondents' knowledge and awareness of tiger nut products and yoghurt. Information included in this section included frequency of purchase, quantity purchase and amount spent on tiger nut and yoghurt within a given time. Another aspect of part two talked about rating of attributes of yoghurt such as colour, taste, sweetness, thickness, consistency, price, general appearance, nutritional level and other attributes. The third part of the questionnaire was dedicated to consumers' perception about tiger nut and yoghurt. The last part of the questionnaires collected data on consumers' willingness to pay for tiger nut yoghurt. 


\section{Methods of data analysis}

Descriptive statistics such as frequencies, percentages, mean and standard deviation were used to summarize the socioeconomic characteristics of the respondents. The important product attributes consumers considered in purchasing yoghurt were also ranked using Kendall's Coefficient of Concordance $(W)$. Kendall's Coefficient of Concordance $(W)$ measures the agreement on the scale of zero to one $(0-1)$, with a value close to one (1) indicating greater agreement in rankings and a value close to zero (0) representing lower ranking agreement. The main hypothesis tested here is as follows:

$H_{0}$ : there is no agreement in the rankings of the attributes of yoghurt by respondents $H_{0}$ : there is agreement in the rankings of the attributes of yoghurt by respondents

Respondents ranked the attributes of yoghurt based on their experiences and decisions. These rankings were used to obtain the $W$ between the respondents, given as:

$$
W=\frac{12 \sum T^{2} j-3 k^{2} N(N+1)^{2}}{k^{2} N\left(N^{2}-1\right)}
$$

Where: $T_{j}$ is column totals, $N$ is number of attributes ranked, $k$ is number of respondents doing the ranking. Since $k$ is greater than 7 , the following quantity is approximately normally distributed as a chi-squared on $N-1$ degrees of freedom:

$$
X_{(N-1)}^{2}=K(N-1) W
$$

Chi-Squared $\left(X^{2}\right)$ estimation and asymptotic significance level were used to determine the level of agreement in the ranking of the attributes. The attributes were categorised into two main perception statements, viz. nutritional/health and purchasing statements. A three (3)-point Likert Scale was also used to analyse consumers' perception about tiger nut yoghurt. The mean score $\hat{X}$ of a perception statement on the Likert Scale was computed as:

$$
\hat{X}=\frac{\sum f_{i j} x_{i j}}{n}
$$

Where $x$ is the ranked value of a perception statement $i$ on the three (3)-point Likert Scale and $f$ is the total number of respondents assigning value $x$ to a perception statement $i$ on the three (3)-point scale. The three (3)-point Likert Scale takes a ranked value of 1 if respondent $j$ agreed to a perception statement $i, 0$ if respondent is undecided (neutral) and -1 if disagreed. The parameter $n$ is equal to the total number of respondents. The overall perception index $(P I)$, which reflects the general agreement of all respondents on all the perception statements on the Likert Scale was computed as:

$$
P I=\frac{\sum \frac{\sum f_{i j} x_{i j}}{n}}{\text { Number of Perception Statements }}
$$

All variables have their usual meaning.

Conceptually, using an indirect utility framework, the economic valuation construct can be represented as:

$$
V_{0}\left(Y_{0}, E_{0}, P_{0}\right)=V_{0}\left(Y_{0}-W T P, E_{1}, P_{0}\right)
$$


where, for a given consumer, $V_{0}$ is a base level of utility, $P_{0}$ represents existing prices, $Y_{0}$ is current income, $E_{1}$ and $E_{0}$ represent the cases of buying the product and not buying the product, respectively. Average consumer WTP is the amount of income a consumer would give up in order to gain a high level of tiger nut yoghurt, $E_{1}$,while maintaining a constant level of utility. Among contingent valuation method (CVM) practitioners, there is no consensus on the optimal bid format. Some researchers prefer one of a number of dichotomous choice elicitation variants, which are thought to simplify the cognitive task faced by respondents while at the same time providing incentives for the truthful revelation of preferences (Hanemann 1989; Cameron and James 1987). Others prefer open-ended formats as an increasing number of empirical studies have revealed that values obtained from dichotomous choice elicitation are significantly and substantially larger than those resulting from comparable open-ended questions (Desvousges et al. 1992; McFadden 1994; Banka et al. 2018). In a comparison of question formats, Reaves et al. (1999) showed that the payment card format exhibited desirable properties pertaining to item non-response and protest bids relative to dichotomous choice and open-ended questions.

The current study employed the double bound contingent valuation model, proposed by Mäler and Vincent (2003) and consisted of asking a second bid (follow-up question) to the respondent after asking the first question. If respondent $i$ answers yes to the first bid, $b_{1 i}$, the second bid $b_{2 i}$ is higher and lower if otherwise. According to the standard procedure, Carson and Hanemann (2005) assumed that respondents' WTPs are independent of the bids and deals with the second response in the same manner as the first discrete choice question. Thus, the double bound model assumes that the same random utility mode generates both responses to the first and the second bids. As each individual is offered two separate bid opportunities, the simplest empirical strategy considers the combination of answers. Defining the potential outcomes as $Y_{i}=(0,1)=($ no, yes $)$ yields $Y_{i}=\left(Y_{i 1}, Y_{i 2}\right)$, the observed outcomes for each individual. Assuming rationality, an individual does not agree to pay more than they are willing. Mathematically, the observed responses yield a set of intervals for estimating WTP which comprises:

$$
\begin{aligned}
Y_{i} & =(1,1)=(\text { yes }, \text { yes }) \\
Y_{i} & =(1,0)=(\text { yes }, \text { no }) \\
Y_{i} & =(0,1)=(\text { no }, \text { yes }) \\
Y_{i} & =(0,0)=(\text { no }, \text { no })
\end{aligned}
$$

For Donaldson et al. (1998), the appropriate technique for econometric analysis of willingness to pay (WTP) data depends firstly on the type of question asked. For example, closed-ended questions and dichotomous choice with follow-up valuation only generate qualitative responses for WTP. This is why it is advised to use discrete choice models such as binary logit and probit for regression analysis (Greene 2005). For data elicited by using a payment scale, the most appropriate econometric methodology is grouped data regression, also called interval regression or ordered logit/probit (Greene 2005; Yasunaga et al. 2006; Bärnighausen et al. 2007). When using an open-ended question or a bidding process, the WTP values obtained are quantitative and several modeling methods have been proposed in the literature. For responses obtained through the 
bidding process, the first regression analysis mostly estimated standard linear models by ordinary least squares (OLS) (O'Brien and Viramontes 1994; Miedzybrodzka et al. 1995). However, the observed data for WTP responses are generally censored. When analyzing the distribution of WTP, we generally observe that the WTP variable does not take values below zero and has positive density at zero. The large proportion of zeros calls into question the continuity of the dependent variable and consequently the use of the classical multiple regression model. In the presence of data censoring, OLS estimation yields biased and inconsistent estimates as a result of its failure to account for the qualitative difference between the limit (zero) observations and non-limit (continuous) observations. Consequently, all conclusions on the determinants of WTP are potentially erroneous (Kurth et al. 2004). Therefore, OLS is one of the least preferred methods to use when it comes to estimating WTP since it cannot capture the full effect of the qualitative data expressed as quantitative data.

The study also posed an open-ended question and the responses for this question were employed in the econometric analysis. Because some variables are censored around zero WTP, Tobit model is an appropriate approach to follow. That is, the Tobit model is the correct alternative frequently proposed for censored data in contingent valuation literature in economics (Kurth et al. 2004). Tobit model is preferred for estimating willingness to pay because it is designed in such a way that it captures the full effect of the variable. Hence the coefficients that are inconsistent and biased in OLS are consistent in Tobit regression. The underlying assumption in the Tobit model is that the same specification is used both for the continuous and the zero decision processes. This implies that the Tobit specification is relevant when all zero realizations represent an economic decision, i.e. a real zero preference for the product under evaluation.

The Tobit model identifies characteristics of consumers that determine WTP for the tiger nut yoghurt. Following Greene (2005), the Tobit model can be generally expressed as:

$$
\begin{array}{ll}
W_{i P}=X_{i} \beta+u_{i} & X_{i} \beta+u_{i}>0 \\
W_{i}=0 & X_{i} \beta+u_{i} \leq 0
\end{array}
$$

where for the $i$ th consumer, $W T P_{i}$ is individual consumer willingness to pay amount, $X_{i}$ is a $k x 1$ vector of known explanatory variables, $\beta$ is a $k x 1$ vector of unknown parameters common to all consumers and $u_{i}$ is a random disturbance term which is independently and normally distributed with zero mean and variance. Then, by using the maximum likelihood estimation, the $\beta s$ are estimated on the basis of $N$ observations on $W T P_{i}$ and $X_{i}$. This is basically an estimation with censored normal regression model. The log likelihood of the Tobit model is specified as:

$$
\ln L=\sum_{y_{i}>0}-\frac{1}{2}\left[\log (2 \pi)+\ln \sigma^{2}+\frac{\left(y_{i}-X_{i}^{\prime} \beta\right)^{2}}{\sigma^{2}}\right]+\sum_{y_{i}=0} \ln \left[\frac{1-\phi\left(X_{i}^{\prime} \beta\right)}{\sigma}\right]
$$

That is, maximizing this likelihood function with respect to $\beta$ and $\sigma$ gives the maximum likelihood estimates of these parameters. Empirically, Table 1 presents a description of the variables employed in the model. Assuming the random error is independent and normally distributed across respondents, the expected WTP for an observation drawn at random is: 
Table 1 Variables employed in the study and their a priori expectations

\begin{tabular}{|c|c|c|c|}
\hline Variable & Description & $\begin{array}{l}\text { A priori } \\
\text { Expectation }\end{array}$ & Source \\
\hline Willingness to Pay (WTP) & $\begin{array}{l}\text { Amount consumers are willing } \\
\text { to pay for } 500 \mathrm{ml} \text { of tiger nut } \\
\text { yoghurt (Ghל) }\end{array}$ & & \\
\hline Age & $\begin{array}{l}\text { Age of consumer, measured in } \\
\text { years }\end{array}$ & - & $\begin{array}{l}\text { Loureiro and McCluskey (2000), } \\
\text { Bee and Selamat (2010), Yahaya } \\
\text { et al. (2015) and Dolgopolova } \\
\text { and Teuber (2016). }\end{array}$ \\
\hline Sex & $\begin{array}{l}\text { Gender of consumer, measured } \\
\text { as a dummy, } 1 \text { for male and } \\
0 \text { otherwise }\end{array}$ & $+/-$ & $\begin{array}{l}\text { Yahaya et al. (2015), Bee and } \\
\text { Selamat (2010) }\end{array}$ \\
\hline Education & $\begin{array}{l}\text { Educational level of consumer, } \\
\text { measured in both levels of } \\
\text { education and years of schooling }\end{array}$ & + & $\begin{array}{l}\text { Noor et al. (2010), Bee and } \\
\text { Selamat (2010) and Balogh } \\
\text { et al. (2016) }\end{array}$ \\
\hline Household size & $\begin{array}{l}\text { Number of individuals living with } \\
\text { respondent }\end{array}$ & - & Bee and Selamat (2010) \\
\hline Monthly Income & Consumer's monthly income (Ghל) & + & $\begin{array}{l}\text { Loureiro and McCluskey (2000), } \\
\text { Basarir et al. (2009), Bee and } \\
\text { Selamat (2010), Meng et al. (2014), } \\
\text { Fang 2015; Yahaya et al. (2015), } \\
\text { Balogh et al. (2016), Dolgopolova } \\
\text { and Teuber (2016) }\end{array}$ \\
\hline Price of yoghurt & $\begin{array}{l}\text { Price consideration in purchasing } \\
\text { yoghurt, measured as a dummy, } \\
1 \text { if consumer considers price } \\
\text { when purchasing yoghurt and } \\
0 \text { otherwise }\end{array}$ & - & Bee and Selamat (2010) \\
\hline General Appearance & $\begin{array}{l}\text { Appearance consideration in } \\
\text { purchasing yoghurt, measured } \\
\text { as a dummy, } 1 \text { if consumer } \\
\text { considers the appearance of the } \\
\text { yoghurt when purchasing it and } \\
0 \text { otherwise }\end{array}$ & + & Straub and Thomassin (2006) \\
\hline Awareness & $\begin{array}{l}\text { Awareness of yoghurt being } \\
\text { produced from tiger nut, measured } \\
\text { as a dummy, } 1 \text { if consumers are } \\
\text { aware of producing yoghurt from } \\
\text { tiger nut and } 0 \text { otherwise }\end{array}$ & + & Gil and Soler (2006) \\
\hline
\end{tabular}

$$
E(W T P)=\Phi\left(\frac{X \beta}{\sigma}\right) X \beta+\sigma \phi\left(\frac{X \beta}{\sigma}\right)
$$

where $\Phi$ represents the normal distribution function, $\phi$ represents the normal density function, and $\sigma$ represents the standard deviation. Furthermore, the expected value of WTP for observations above zero, here called $E\left(W T P^{*}\right)$, is simply $X \beta$ plus the expected value of the truncated normal error terms (Greene 2005). Then, the expected WTP can be expressed as:

$$
E(W T P)=\Phi\left(\frac{X \beta}{\sigma}\right) E\left(W T P^{*}\right)
$$

It should be noted that unlike linear models, the marginal effect or partial derivative for a given explanatory variable is nonlinear and thus not equal to $\beta_{i}$. The decomposition 
of this marginal effect that is obtained by considering the effect of a change in the ith variable of $X$ on WTP is expressed as:

$$
\frac{\partial E(W T P)}{\partial X_{i}}=\Phi\left(\frac{X \beta}{\sigma}\right)\left(\frac{\partial E\left(W T P^{*}\right)}{\partial X_{i}}\right)+\left(W T P^{*}\right)\left(\frac{\partial \Phi\left(\frac{X \beta}{\sigma}\right)}{\partial X_{i}}\right)
$$

Intuitively, the total change in WTP can be disaggregated into two parts: (1) the change in WTP of the above zero bids, weighted by the probability of being above the zero bid; and (2) the change in the probability of being above the zero bid, weighted by the expected value of WTP if above the zero bid. Equation (14) can be evaluated at the mean of the Xs, $\bar{X}$ with estimates of $\beta$ and $\sigma$. The fraction of the total marginal effect due to the effect above the zero bid is

$$
\frac{\partial E\left(W T P^{*}\right)}{\partial X_{i}}=1-\frac{X \beta \phi\left(\frac{X \beta}{\sigma}\right)}{\Phi\left(\frac{X \beta}{\sigma}\right)}-\frac{\phi\left(\frac{X \beta}{\sigma}\right)^{2}}{\Phi\left(\frac{X \beta}{\sigma}\right)^{2}}
$$

We estimated total marginal effect, $\frac{\partial E(W T P)}{\partial X_{i}}$, using Eq. (14) and the fraction of the total marginal effect above the zero bid, $\frac{\partial E\left(W T P^{*}\right)}{\partial X_{i}}$, using Eq. (15).

We assume in this paper that the discrete decision of willingness to pay for tiger nut yoghurt and the continuous decision of the amount consumers are willing to pay are made simultaneously and that the same factors had the same effects on the two decisions. The Tobit model is able to combine the probit and truncated models of Cragg's Double Hurdle Model to obtain the joint coefficient, $\alpha$, in case the two aforementioned decisions are jointly made, which explains both the discrete decision of willingness to pay for tiger nut yoghurts and the continuous decision of the amount consumers are willing to pay. To confirm the appropriateness of the Tobit model, the Tobit model was tested against Cragg's model by estimating a probit, a truncated regression, and a Tobit model with the same variables $\left(X_{i}\right)$ and computing the following likelihood ratio statistic (Katchova and Miranda 2004; Greene 2005; Wiredu et al. 2015; Asante et al. 2018):

$$
\lambda=2\left(\ln L_{\text {probit }}+\ln L_{\text {truncated regression }}-\ln L_{\text {Tobit }}\right)
$$

where $\lambda$ is distributed as chi-square with $R$ degrees of freedom ( $R$ is the number of independent variables including a constant). The Tobit model will be rejected in favor of Cragg's model if $\lambda$ exceeds the appropriate chi-square critical value.

\section{Results and discussion}

\section{Consumer characteristics and demographics}

The descriptive statistics of the characteristics of the consumers are presented in Tables 2 and 3. The average age of the consumers was 29.7 years (Table 3). This suggests that most of the respondents were quite young. Similar results were reported by Bee and Selamat (2010), Balogh et al. (2016) and Adalja et al. (2017). The average household size was four (4) members and this is consistent with Bee and Selamat (2010). The average monthly income for the consumers was estimated at Gh\$642.19 (US\$145.29). ${ }^{1}$ This follows the findings of Balogh et al. (2016) but is quite low compared to similar 
Table 2 Distribution of Socioeconomic characteristics of respondents

\begin{tabular}{|c|c|c|}
\hline Variable & Frequency & Percentage \\
\hline \multicolumn{3}{|c|}{ Educational level of consumer } \\
\hline No formal education & 25 & 8 \\
\hline Primary & 19 & 6 \\
\hline $\mathrm{JSS} / \mathrm{JHS}$ & 41 & 13 \\
\hline SSS/SHS & 98 & 31 \\
\hline Tertiary & 132 & 42 \\
\hline Total & 315 & 100 \\
\hline \multicolumn{3}{|l|}{ Marital status } \\
\hline Married & 126 & 40 \\
\hline Unmarried & 189 & 60 \\
\hline Total & 315 & 100 \\
\hline \multicolumn{3}{|l|}{ Ethnic Affiliation } \\
\hline Akan & 252 & 80 \\
\hline Ga & 12 & 3.8 \\
\hline Ewe & 19 & 6 \\
\hline Gonja & 3 & 1 \\
\hline Dagomba & 8 & 2.5 \\
\hline Frafra & 5 & 1.6 \\
\hline Others & 16 & 5.1 \\
\hline Total & 315 & 100 \\
\hline \multicolumn{3}{|l|}{ Religious affiliation } \\
\hline Christianity & 287 & 91.1 \\
\hline Muslim & 21 & 6.7 \\
\hline Traditionalist & 2 & 0.6 \\
\hline Others & 5 & 1.6 \\
\hline Total & 315 & 100 \\
\hline \multicolumn{3}{|l|}{ Occupation of respondent } \\
\hline Public worker & 69 & 22 \\
\hline Private worker & 60 & 19 \\
\hline Self employed & 110 & 35 \\
\hline Unemployed & 38 & 12 \\
\hline Others & 38 & 12 \\
\hline Total & 315 & 100 \\
\hline \multicolumn{3}{|c|}{ Awareness of tiger nut yoghurt } \\
\hline Aware & 24 & 7.6 \\
\hline Unaware & 291 & 92.4 \\
\hline Total & 315 & 100.0 \\
\hline \multicolumn{3}{|c|}{ Consumer enjoys tiger nut } \\
\hline Yes & 265 & 84 \\
\hline No & 50 & 16 \\
\hline Total & 315 & 100.0 \\
\hline \multicolumn{3}{|c|}{ Place of Purchase of Yoghurt } \\
\hline Open market & 224 & 71 \\
\hline Super market & 38 & 12 \\
\hline
\end{tabular}


Table 2 Distribution of Socioeconomic characteristics of respondents (Continued)

\begin{tabular}{lll}
\hline Variable & Frequency & Percentage \\
\hline Store/Shop & 47 & 15 \\
Others & 6 & 2 \\
Total & 315 & 100.0 \\
\hline
\end{tabular}

Source: Field survey, 2017

results reported by Adalja et al. (2017). About 40\% of the respondents are married while $60 \%$ are either single or divorced. The results revealed that most of the respondents $(92 \%)$ had at least primary level of education with $42 \%$ obtaining tertiary education indicating low illiteracy rate (Table 2). This finding has implication on tiger nut yoghurt market segmentation and price discrimination. That is, different markets could be established for different consumer groups depending on their educational levels and higher prices set for the highly educated while lower prices are set for those with little or no formal education. This however contradicts the findings of Adu et al. (2015) that reported higher illiteracy rate among potential potatoe yoghurt consumers. Majority of the respondents were Akans who constituted $80 \%$ of the sample. This was not surprising as the study was conducted in the Ashanti region of Ghana which naturally, is dominated by the Akans. Table 2 presents the distribution of religious affiliation of the respondents. It is also interesting to note that over $90 \%$ of the respondents were Christians. Clearly, most of the respondents (35\%) were self-employed and $41 \%$ comprising both public (22\%) and private (19\%) workers were salaried workers. This is in line with similar findings reported by KMA (2013). Generally, most respondents (over 90\% ofthem) had no knowledge of the possibility of yoghurt being produced from tiger nut. That notwithstanding, majority of them (84\%) indicated they really enjoyed taking tiger nut owing to its nutritional and health benefits. In fact, as high as $71 \%$ of the sampled consumers indicated they always bought their yoghurt from the open market. The remaining $29 \%$ either bought theirs from the store/shop (15\%), supermarket (12\%) and others (2\%). This finding confirms the findings of Meng et al. (2014) that reported the dominance of food store/shop and open market as shopping places in developing countries where supermarkets are gradually being accepted by urban household.

\section{Important product attributes consumers consider during purchasing}

Table 4 presents the results of the product attributes consumers look out for when buying yoghurt. The results indicate that with a mean of 1.38 , the most important attribute consumers considered in purchasing yoghurt was the nutritional benefits they derived from consuming it. This was followed by taste, sweetness, health benefits, consistency,

Table 3 Descriptive statistics of continuous variables employed in the study

\begin{tabular}{lllll}
\hline Variable & Minimum & Maximum & Mean & Standard deviation \\
\hline Age of respondent (years) & 17 & 69 & 29.7 & 8.0 \\
Years of formal education & 0 & 20 & 11.9 & 4.9 \\
Monthly income (Ghc) & 0 & 3000 & 642.2 & 464.9 \\
Household size & 1.00 & 20.00 & 4 & 2 \\
\hline
\end{tabular}

Source: Field Data, 2017 
Table 4 Rank of product attributes considered during purchasing

\begin{tabular}{lll}
\hline Attributes & Mean Rank & Rank \\
\hline Nutritional benefits & 1.38 & 1st \\
Taste & 2.41 & 2nd \\
Sweetness & 2.64 & $3 \mathrm{rd}$ \\
Health benefits & 4.38 & 4th \\
Consistency & 6.34 & 5 th \\
Colour & 6.75 & 6th \\
Price & 7.21 & 7 th \\
Thickness & 7.89 & 8 th \\
Appearance & 8.78 & 9 th \\
Others & 9.89 & 10th \\
Number of observation & 315 & \\
Kendall's W & 0.813 & \\
Chi-Squared & 624.45 & 9 \\
Df & 9.000 & \\
Asymp. Sig & &
\end{tabular}

Source: Field Survey, 2017

colour, price, thickness and appearance. The implication is that consumers have become very conscious of the type of nutrients present in the food they buy. That is, they will not buy any food that does not meet their nutritional requirements. This finding is consistent with similar results reported by Bee and Selamat (2010). Taste of yoghurt is also important to consumers, indicating that the demand for tiger nut yoghurt will be higher if it is made tastier than other yoghurts found on the market. In addition, ranking as the 4th attribute with a mean of 4.38 , consumers considered health benefits as very important in their purchases. The implication is that if efforts were made to ensure or guarantee that tiger nut yoghurt was healthy, many yoghurt consumers would be willing to pay for it. The above results on taste and health benefits corroborate Balogh et al. (2016) that perceived health benefits and superior tastiness are important attributes considered in purchasing decisions. With price ranking as the 7 th attribute, it means that the prices of tiger nut yoghurt will not all that be an issue as long as it proves to be nutritionally beneficial and healthy. Therefore, improving the nutritional and health benefits of the product has the potential to increase its market demand.

The results also revealed Kendall's Coefficient of Concordance $(W)$ of 0.813 in the ranking of the attributes of yoghurt. The implication is that there is a strong agreement among respondents in the ranking of the attributes and this is statistically significant at the $1 \%$ level. Therefore, the null hypothesis which states that; "there is no significant agreement among respondents in the ranking of the attributes", was rejected.

\section{Consumers' perception of tiger nut yoghurt}

Table 5 presents the results of two categories of perception statements (health/nutrition and purchasing) that were analysed in this study. It could be inferred from the table that $42.9 \%$ of the respondents agreed that tiger nut helped reduce malnutrition and $34.9 \%$ were neutral to this statement. Most of the respondents (51.4\%) also perceived 
Table 5 Distribution of respondent's perception of tiger nut yoghurt

\begin{tabular}{|c|c|c|c|c|}
\hline Statements & Agree (1) & Neutral (0) & Disagree $(-1)$ & $\begin{array}{l}\text { Mean } \\
\text { Scores } \\
\end{array}$ \\
\hline \multicolumn{5}{|l|}{ Health/Nutrition Statements } \\
\hline A. Tiger nut help reduce malnutrition & $135(42.9)$ & $110(34.9)$ & $70(22.2)$ & 0.20 \\
\hline B. Tiger nut is essential for fertility in both men and women & $96(31.1)$ & $136(43.2)$ & $81(25.7)$ & 0.04 \\
\hline C. Tiger nut help prevent cancer & $98(31.1)$ & $136(43.2)$ & $81(25.7)$ & 0.05 \\
\hline $\begin{array}{l}\text { D. Tiger nut is sweet already so I don't need much } \\
\text { white sugar }\end{array}$ & $162(51.4)$ & $96(30.5)$ & $57(18.1)$ & 0.30 \\
\hline E. Tiger nut food products help reduce constipation & $102(32.4)$ & $130(41.3)$ & $83(26.3)$ & 0.06 \\
\hline $\begin{array}{l}\text { F. Tiger nuts have low sugar level and help reduce the risk } \\
\text { of diabetes }\end{array}$ & $136(43.2)$ & $106(33.7)$ & $73(23.2)$ & 0.20 \\
\hline G. Tiger nuts help prevent heart disease & $112(35.6)$ & $115(36.5)$ & $88(27.9)$ & 0.07 \\
\hline Health/Nutritional Perception Index & & & & 0.31 \\
\hline \multicolumn{5}{|l|}{ Purchasing Statements } \\
\hline $\begin{array}{l}\text { A. Tiger nut yoghurt is likely to be less expensive compared } \\
\text { to other yoghurts }\end{array}$ & $117(37.1)$ & $125(39.7)$ & $73(23.2)$ & 0.13 \\
\hline $\begin{array}{l}\text { B. I will choose tiger nut yoghurt ahead of the other } \\
\text { yoghurts on the market if they all sell at the same price }\end{array}$ & $161(51.1)$ & $119(37.8)$ & $35(11.1)$ & 0.40 \\
\hline $\begin{array}{l}\text { C. I am willing to pay a little higher for tiger nut yoghurt } \\
\text { due to its health and nutritional benefits }\end{array}$ & $186(59.0)$ & $101(32.1)$ & $28(8.9)$ & 0.50 \\
\hline $\begin{array}{l}\text { D. I will be willing to buy tiger nut yoghurt only if it is } \\
\text { well-packaged }\end{array}$ & $192(60.9)$ & $102(32.4)$ & $20(6.3)$ & 0.54 \\
\hline E. I will be willing to buy tiger nut yoghurt only if it is labelled & $175(55.6)$ & $114(36.2)$ & $26(8.3)$ & 0.47 \\
\hline $\begin{array}{l}\text { F. I will be willing to buy tiger nut yoghurt if the health claims } \\
\text { are displayed on the product }\end{array}$ & $200(63.5)$ & $96(30.5)$ & $19(6.3)$ & 0.57 \\
\hline Purchasing Perception Index (PPI) & & & & 0.36 \\
\hline Overall mean perception index & & & & 0.67 \\
\hline
\end{tabular}

Source: Field Survey, 2017

that tiger nut is sweet already and therefore there was no need for much white sugar to be added to tiger nut yoghurt, making it healthier (Table 5). The respondents claim that it can even be used as a sweetener for especially diabetic diets that are expected to be sugar free. Even though $30.5 \%$ of the respondents agreed that tiger nut based products helped improve fertility in both men and women, $43.2 \%$ were indifferent (Table 5). In the same proportions, with $31.1 \%$ agreeing that tiger nut helps reduce the risk of cancer, $43.1 \%$ of them were neutral about the statement. Similar results were obtained about the respondents' view on the potential of tiger nut yoghurt in reducing constipation as $32.3 \%$ agreed and $41.3 \%$ were indifferent. On their perception of the product in reducing diabetes, $43.2 \%$ agreed, $33.7 \%$ were neutral and $23.2 \%$ disagreed (Table 5). In fact, commenting on the potential of tiger nut yoghurt to prevent heart diseases, only $35.6 \%$ agreed (Table 5). The mean perception index for the health/nutritional statements was 0.31 , suggesting the respondents had a positive perception of tiger nut yoghurt as being healthy and nutritionally beneficial. The above finding agrees with similar results reported by similar previous studies (Loureiro and McCluskey 2000; Bee and Selamat 2010).

While $37.1 \%$ of the respondents agreed that tiger nut yoghurt is likely to be less expensive compared to other yoghurts on the market, to $39.7 \%$ of them, they were indifferent. Also, over $50 \%$ of the respondents agreed they would choose tiger nut yoghurt ahead of 
other yoghurts on the market if they all sold at the same price (Table 5). This implies that respondents perceived tiger nut yoghurt provided some benefits that were lacking in other yoghurts. In addition, it is interesting to note that $59.0 \%$ of the sampled consumers were willing to pay a little higher for tiger nut yoghurt vis-à-vis other yoghurts due to its health and nutritional benefits. This also confirms the results presented in Table 4 that price in particular is not an issue as long as tiger nut yoghurt has proven to be beneficial. The results also depict the great value customers place on this product. Moreover, $60.9 \%$ of the respondents agreed they will be willing to buy tiger nut yoghurt if it was packaged well (Table 5). According to them, such a product will substitute well for tiger nuts sold on the streets which are perceived to be unclean and unsafe for consumption. Also with tiger nut's perceived aphrodisiac properties, many people feel shy to buy it on the street but they will be more comfortable buying its well packaged yoghurt. Furthermore, most of the respondents (55.6\%) found labelling to be important and therefore indicated they will be willing to buy tiger nut yoghurt only if it is well labelled (Table 5). This is not surprising since the analysis above has provided evidence of respondents' willingness to buy the product once it proves to be healthy and nutritionally beneficial. The point is that, consumers can only be sure of a quality product only when it is well labelled. Finally, over $60 \%$ of the respondents agreed that they would be willing to buy tiger nut yoghurt if the health claims are displayed while $30.5 \%$ were indecisive (Table 5). This result is also not surprising because consumers would want to see a confirmation of their perception of the health benefits of tiger nut yoghurt. The mean perception index of $0.36 \%$ for the respondents' purchasing behaviour shows that, generally, the respondents have a positive perception towards purchasing of tiger nut yoghurt (Table 5). The overall mean perception index was 0.67 , indicating that the respondents have positive perception towards the attributes of tiger nut yoghurt (Table 5).

That is, almost all respondents agree to the attributes.

\section{Willingness to pay for tiger nut yoghurt}

Table 6 distinguishes between the characteristics of consumers who were willing to pay (WTP) and those who were unwilling to pay (UWTP) a premium for tiger nut yoghurt in the study area. The mean difference for most of the characteristics (age, sex, household size, education, income, price attribute) are statistically significant, suggesting existence of some differences in the aforementioned characteristics between respondents who expressed WTP and those UWTP premiums for tiger nut yoghurt. Notably, the mean household monthly income of respondents who were WTP premiums was significantly higher than the mean income of those who were UWTP premiums.

The results of analysis of respondents' willingness to pay a premium for tiger nut yoghurt are summarized in Table 7 . The results showed that most respondents were willing to pay relatively higher premium for tiger nut yoghurt vis-à-vis other yoghurts. The price of $500 \mathrm{ml}$ of 'normal' yoghurt at the time the study was conducted was Ghc 2.50 (US\$0.57). Meanwhile respondents with the Yes-Yes responses representing 49.2\% of the sampled consumers were willing to pay Gh\$3.50 (US\$0.79) for $500 \mathrm{ml}$ of tiger nut yoghurt. The implication is that yoghurt consumers placed some value on tiger nut yoghurt and this could be due to the positive perception they had for the product, especially the perceived nutritional and health benefits and attributes (Tables 4 and 5). This 
Table 6 Differences in characteristics of consumers who are WTP and those UWTP

\begin{tabular}{lllll}
\hline Characteristic & WTP & UWTP & Mean difference & $t$-value \\
\hline Age of respondent & 28.84 & 30.54 & 1.70 & $5.92^{* * *}$ \\
Sex & 0.465 & 0.455 & -0.01 & $3.41^{* *}$ \\
Household size & 4.624 & 5.214 & 0.59 & $2.85^{* *}$ \\
Years of formal education & 12.96 & 4.306 & -8.65 & $6.18^{* * *}$ \\
Monthly income & 660.4 & 622.3 & -38.1 & $5.38^{* * *}$ \\
Awareness & 1.941 & 1.903 & -0.04 & 6.47 \\
General appearance & 0.512 & 0.538 & 0.03 & 1.48 \\
Price attribute & 0.718 & 0.745 & 0.03 & $2.47^{*}$ \\
\hline
\end{tabular}

***significant at $1 \%,{ }^{* *}$ significant at $5 \%,{ }^{*}$ significant at $10 \%$

Source: Field Survey, 2017

finding corroborates similar results reported by previous studies conducted in Ghana and other parts of the world that nutritional and health benefits of food products influence consumers to be willing to pay higher prices for them (Loureiro and McCluskey 2000; Bee and Selamat 2010; Yahaya et al. 2015; Balogh et al. 2016; Adalja et al. 2017). The results also showed that very few of the sampled consumers (2.2\%) expressed their unwillingness to patronize the product. The foregoing presents good news to Sanful (2009) given the high prospects of tiger nut yoghurt.

\section{Factors influencing willingness to pay for tiger nut yoghurt}

The results of the probit, truncated regression and Tobit models employed in determining the factors that influence consumers' willingness to pay a premium for tiger nut yoghurt as well as the amount they are willing to pay are presented in Table 8. The calculated likelihood ratio statistic is 12.12 and is well below the tabulated value (21.67). Hence we can say that the Tobit model better fits our data than the Cragg's model. This implies that the decisions about a consumer's willingness to pay for tiger nut yoghurt and the amount he/she is willing to pay are jointly made. Hence, from here on discussions are based on the findings of the Tobit model. The likelihood ratio statistic of 73.93 is statistically significant at the $1 \%$ level indicating that at least one of the regression coefficients in the model is not equal to zero. The results showed that consumers' willingness to pay (WTP) for tiger nut yoghurt is influenced by age, sex, educational level, household size, monthly income and price of the product.

The coefficient of age is negatively related to consumers' WTP amount for tiger nut yoghurt and statistically significant at the $1 \%$ level. Specifically, an increase in the age of a yoghurt consumer by 1 year will decrease his/her WTP amount for tiger nut

Table 7 Distribution of respondents' willingness to pay

\begin{tabular}{llll}
\hline Response & Price & Frequency & Percentage \\
\hline Yes-Yes responses & 3.5 & 155 & 49.2 \\
Yes-No responses & 3.0 & 28 & 8.9 \\
No-Yes responses & 2.5 & 125 & 39.7 \\
No-No responses & $<2.5$ & 7 & 2.2 \\
Total & & 315 & 100 \\
\hline
\end{tabular}

Source: Field Survey, 2017 
Table 8 Probit, Truncated and Tobit regression estimates for willingness to pay

\begin{tabular}{|c|c|c|c|c|c|c|}
\hline \multirow[t]{2}{*}{$\overline{W T P}$} & \multicolumn{2}{|l|}{ Probit } & \multicolumn{2}{|c|}{ Truncated } & \multicolumn{2}{|l|}{ Tobit } \\
\hline & $\overline{\text { Coeff }}$ & SE & $\overline{\text { Coeff }}$ & SE & Coeff & SE \\
\hline Age & $-0.003^{*}$ & 0.034 & -0.001 & 0.004 & $-0.024^{* * *}$ & 0.009 \\
\hline Sex & 0.018 & 0.005 & $0.142^{* *}$ & 0.009 & $0.234^{*}$ & 0.127 \\
\hline Years of Education & 0.002 & 0.010 & 0.058 & 0.016 & $0.024^{*}$ & 0.014 \\
\hline Household Size & -0.046 & 0.015 & -0.042 & 0.001 & $-0.056^{* *}$ & 0.026 \\
\hline Monthly Income & $0.158^{* *}$ & 0.081 & $0.071^{*}$ & 0.023 & $0.0002^{* *}$ & 0.0001 \\
\hline Price of yoghurt & $-0.006^{* *}$ & 0.002 & $-0.041^{*}$ & 0.007 & $-0.328^{* *}$ & 0.133 \\
\hline General Appearance & $0.019^{*}$ & 0.004 & 0.008 & 0.063 & 0.062 & 0.087 \\
\hline Awareness & 0.587 & 0.028 & 0.036 & 0.047 & 0.161 & 0.279 \\
\hline Constant & -1.345 & 0.415 & $0.275^{* *}$ & 0.054 & 0.268 & 0.664 \\
\hline Number of obs & 315 & & 287 & & 315 & \\
\hline LR chi2(8) & $37.48^{* * *}$ & & $58.22^{* * *}$ & & $73.93^{* * *}$ & \\
\hline Pseudo R2 & 0.214 & & & & 0.0627 & \\
\hline Log likelihood & -269.23 & & -20.23 & & -295.52 & \\
\hline Likelihood ratio statistic & 12.12 & & & & & \\
\hline
\end{tabular}

SE denotes standard errors and ${ }^{* * *}$ significant at $1 \%$, ** significant at $5 \%$, ${ }^{*}$ significant at $10 \%$ Source: Field Survey, 2017

yoghurt by 0.024 . This implies that younger consumers will prefer paying more to get tiger nut yoghurt vis-à-vis older ones. This is not surprising as the average age of the respondents showed that yoghurt consumers are quite young (Table 3). This fact can also be explained by the results in Table 6 that statistically, there is a significant difference between the ages of consumers who are willing to pay a premium for tiger nut yoghurt and those unwilling to make such payments and that those willing to pay are relatively younger. Generally, older people opined that tiger nut yoghurt will not be as natural as chewing raw tiger nut the traditional way as they perceive the yoghurt version will be adulterated with additives, hence their preference for raw tiger nuts. The negative effect of age on consumers' WTP amount for tiger nut yoghurt corroborates similar results obtained by Loureiro and McCluskey (2000), Bee and Selamat (2010), Yahaya et al. (2015) and Dolgopolova and Teuber (2016).

The results also showed that male gender has a positive effect on the WTP amount and is statistically significant at the $10 \%$ level indicating that males will be willing to pay higher premiums for tiger nut yoghurt (Table 8). If a customer is male, his expected WTP amount would be 0.234 higher than a customer who is female. Table 6 also presents similar statistically significant higher WTP premiums of male consumers vis-à-vis females. This could be due to the perceived aphrodisiac properties of tiger nuts and given that most men feel shy to buy them on the street, they will be willing to pay more for any product with tiger nut as an ingredient. The aforementioned results of more males willing to pay higher premium for tiger nut yoghurt is consistent with those of Yahaya et al. (2015) even though it disagrees with those of Bee and Selamat (2010) that females are generally willing to pay more for food products with "No Added MSG" labeling as compared to males.

The results also revealed that education has a positive effect on the premium consumers will be willing to pay for tiger nut yoghurt. This is significant at the $10 \%$ level. The results further showed that an increase in educational level of the consumer by 
one more year will increase his/her WTP amount for tiger nut yoghurt by 0.024 , all things being equal. Table 6 buttresses this finding by presenting results that indicate a statistically significant difference bewteen the educational level of consumers who are willing to pay a premium for tiger nut yoghurt and those unwilling to pay. The results showed that those willing to pay a premium have at least senior secondary or senior high school education whereas those UWTP have at most primary school education. The positive effect of education on WTP could be due to the fact that education makes individuals health and nutritionally conscious. That is, education makes them aware of the health and nutritional benefits of all kinds of foods, giving them the opportunity to choose foods that meet their health and nutritional needs. The positive effect of education on WTP in the current study is in line with similar results obtained by Noor et al. (2010), Bee and Selamat (2010) and Balogh et al. (2016).

Moreover, the coefficient of household size is negative and statistically significant at the $5 \%$ level (Table 8). The coefficient also revealed that with every increase in household size by one member, consumers' WTP amount reduces by 0.056 . This is true as Table 6 also presents statistically significant smaller household sizes of consumers who are WTP. This is because consumers with large household size are less likely to spend more on yoghurt and other soft drinks because they have huge household commitments that put pressure on their monthly budgets and therefore little is always left for purchasing yoghurt and other soft drinks. This finding corroborate Bee and Selamat (2010) that also reported a significant negative relationship between household size and WTP amount.

Furthermore, monthly income is statistically significant at the $5 \%$ level and has a positive influence on WTP amount for tiger nut yoghurt (Table 8). The results further showed that as household monthly income increases by Gh\$1.00 (US\$0.23), consumers' WTP amount for tiger nut yoghurt will increase by 0.0002 (Table 8 ). This compares well with the results in Table 6 that reports statistically significant relatively higher incomes of consumers who are WTP. The implication is that income plays a role in deciding whether or not to accept a new food product. That is, consumers may wish to demand a food product especially when it is proven to be healthy and nutritionally beneficial but low incomes could prevent them from patronizing it. This is consistent with the findings of earlier studies on consumers' WTP amounts for new food products (Loureiro and McCluskey 2000; Basarir et al. 2009; Bee and Selamat 2010; Meng et al. 2014; Fang 2015; Yahaya et al. 2015; Balogh et al. 2016; Dolgopolova and Teuber 2016) consumers with high income were willing to pay high for labelled food products.

Finally, price consideration in purchasing yoghurt is negatively related to consumers' WTP amount and statistically significant at the $5 \%$ level. The coefficient implies that if a consumer considers price before purchasing yoghurt, his/her expected WTP amount would be 0.328 lower than a customer who does not consider price. Table 6 also shows that those who were willing to pay a premium for tiger nut yoghurt were consumers who were indifferent about the price of the product. Rational as those who consider price may be, given other substitutes, they will shift to the substitute with the lower price. It is important to state that this finding does not in any way mean that consumers are unwilling to pay for tiger nut yoghurt as the variable was measured conditionally. The finding compares well with Bee and Selamat (2010) that concluded that price-sensitive consumers will generally not be willing to pay for a new food product. 


\section{Conclusion and recommendation}

The study assessed consumers' perception and willingness to pay for tiger nut yoghurt developed by Sanful (2009) in the Kumasi Metropolis of Ghana. The findings were that generally, most respondents had no knowledge of the possibility of yoghurt being produced from tiger nut. That notwithstanding, majority of them indicated they really enjoyed taking tiger nut owing to its nutritional and health benefits and they always bought their yoghurt from the open market.

Also, the most important attribute consumers considered in purchasing yoghurt was the nutritional benefits they derived from consuming it. The implication is that consumers have become very conscious of the type of nutrients present in the food they buy, making a substantial number of them agree that tiger nut helped reduce malnutrition. This was followed by taste, sweetness, health benefits, consistency, colour, price, thickness and appearance.

In addition, the average monthly income for the consumers was Gh\$642.19 (US\$145.29). Notably, the mean household monthly income of respondents who were WTP premiums was significantly higher than that of those who were UWTP premiums. Generally, most respondents were willing to pay relatively higher premium for tiger nut yoghurt vis-à-vis other yoghurts. Even though the price of $500 \mathrm{ml}$ of 'normal' yoghurt was Gh $\$ 2.50$ (US\$0.57), consumers were willing to pay Gh $\$ 3.50$ (US\$0.79) for the same volume. The implication is that yoghurt consumers placed some value on tiger nut yoghurt vis-à-vis other yoghurts and this could be due to the positive perception they had for the product, especially the perceived nutritional and health benefits and attributes. The foregoing presents good news to Sanful (2009) and other would-be investors as well as entrepreneurs and most importantly, the unemployed who may want to support commercialization of the product through doing a business in its production and marketing.

Moreover, an increase in the age of a yoghurt consumer by 1 year will decrease his/ her WTP amount for tiger nut yoghurt. This implies that younger consumers will prefer paying more to get tiger nut yoghurt vis-à-vis older ones. This is not surprising as the average age of the respondents showed that yoghurt consumers are quite young. If a customer is male, his expected WTP amount would be higher than a customer who is female. This could be due to the perceived aphrodisiac properties of tiger nuts and given that most men feel shy of buying them on the street, they will be willing to pay more for any product with tiger nut as an ingredient. An increase in educational level of the consumer by one more year will increase his/her WTP amount for tiger nut yoghurt, all things being equal. This could be due to the fact that education makes individuals health and nutritionally conscious.

Furthermore, the study revealed that with every increase in household size by one member, consumers' WTP amount reduces. This is because consumers with large household size are less likely to spend more on yoghurt and other soft drinks because they have huge household commitments that put pressure on their monthly budgets and therefore little is always left for purchasing yoghurt and other soft drinks. As household monthly income increases, consumers' WTP amount for tiger nut yoghurt will increase. The implication is that income plays a role in deciding whether or not to accept a new food product. That is, consumers may wish to demand a food product especially when it is proven to be healthy and nutritionally beneficial but low incomes could prevent them from patronizing it. 
Finally, if a consumer considers price before purchasing yoghurt, his/her expected WTP amount would be lower than a customer who does not consider price. That is, those who were willing to pay a premium for tiger nut yoghurt were consumers who were indifferent about the price of the product.

From the foregoing, it is clear that the new product developed from tiger nut (tiger nut yoghurt) by Sanful (2009) has bright market prospects in the Kumasi metropolis and similar urban settings and can help create jobs for the unemployed if they are to consider its production and marketing as a business. This will contribute to Ghana's strive to achieving the first three Sustainable Development Goals (SDGs), viz. no poverty, zero hunger as well as good health and well-being. The study recommends that tiger nut yoghurt should be introduced into the metropolis. There is however the need to increase awareness and education on the nutritional and health benefits of tiger nut since education has a positive influence on consumers' willingness to pay for food products. There is also the need for a profitability analysis of tiger nut yoghurt production to make available information on costs, revenue and profitability of the venture to prospective investors. The product too should be well packaged and well labelled in different sizes to allow price-sensitive consumers who cannot afford to pay a premium to be able to purchase it.

\section{Endnotes \\ ${ }^{1} 1.00$ US $\$=$ Gh $\$ 4.42$}

Abbreviations

CVM: Contingent valuation method; KMA: Kumasi Metropolitan Assembly; OLS: Ordinary least squares; PI: Perception index; SDGs: Sustainable Development Goals; UWTP: Unwilling to pay; WTP: Willingness to pay

\section{Acknowledgements}

We thank all the workers at Boadi Dairy Research Station of Kwame Nkrumah University of Science and Technology, Kumasi, Ghana, who gave us the needed attention and support during our experiment at the station. We are also grateful to the respondent tiger nut and yoghurt consumers in the Kumasi Metropolis without whose co-operation the study could not have taken place.

Funding

Not applicable.

Availability of data and materials

The dataset used in this study is available from the corresponding author on reasonable request.

\section{Authors' contributions}

CAW conceived the idea and worked on all sections. AF worked on the introduction and the conclusion. RKB worked on literature relevant to the study. DAV worked on the methods of analysis and discussion of the results. IM participated in data collection, data entry and data analysis. BAO participated in data collection and worked on results and discussion. YOA helped data collection and AA participated in data collection and writing the conclusion of this study. All authors read and approved the final manuscript.

Competing interests

The authors declare that they have no competing interests.

\section{Publisher's Note}

Springer Nature remains neutral with regard to jurisdictional claims in published maps and institutional affiliations.

Author details

${ }^{1}$ Department of Agricultural Economics, Agribusiness and Extension, Kwame Nkrumah University of Science and Technology, Private Mail Bag, University Post Office, Kumasi, Ghana. ${ }^{2}$ Department of Agricultural Economics, Agribusiness and Extension, University of Energy and Natural Resources, Sunyani, Ghana. 
Received: 15 October 2018 Accepted: 7 December 2018

Published online: 04 January 2019

\section{References}

Adalja, A., Hanson, J., \& Towe, C. (2017). An examination of consumer willingness to pay for local products. Agricultural and Resource Economics Review, 44, 253-274.

Adebajo, L. O. (1993). Survey of aflatoxins and ochratoxin a in stored tubers of Cyperus esculentus L. Mycopathologia, 124(1), 41-46.

Adejuyitan, J. A. (2011). Tiger nut processing: its food uses and health benefits. American Journal of Food Technology, 6(3), 197-201.

Adu, E., Acheampong, J. O., Agyapomaa, L. A., Ackun, P. A., \& Asimeng, A. A. (2015). Consumer's perception and willingness to pay for sweet potato yoghurt (potagurt). Unpublished undergraduate thesis, Kwame Nkrumah University of Science and Technology, 2015

Arafat, S. M., Gaafar, A. M., Basuny, A. M., \& Nassef, S. L. (2009). Chufa tubers (Cyperus esculentus L.): As a new source of food. World Applied Sciences Journal, 7(2), 151-156.

Asante, B. O., Villano, R. A., Patrick, I. W., \& Battese, G. E. (2018). Determinants of farm diversification in integrated crop-livestock farming systems in Ghana. Renewable Agriculture and Food Systems, 33(2), 131-149.

Balogh, P., Békési, D., Gorton, M., Popp, J., \& Lengyel, P. (2016). Consumer willingness to pay for traditional food products. Food Policy, 61, 176-184. https://doi.org/10.1016/j.foodpol.2016.03.005.

Banka, M., Aidoo, R., Abaidoo, R., Fialor, S., \& Masso, C. (2018). Willingness to pay for biofertilizers among grain legume farmers in northern Ghana. Journal of Scientific Research and Reports, 19(1), 1-13. https://doi.org/10.9734/jsrr/2018/40457.

Bankole, S. A., \& Adebanjo, A. (2003). Mycotoxins in food in West Africa: current situation and possibilities of controlling it. African Journal of Biotechnology, 2(9), 254-263.

Bannor, R. K., \& Dhaka, S. (2015). Integration of cluster beans markets in Rajasthan state of India. Economic Affairs, $60(3), 529-538$

Bärnighausen, T., Liu, Y., Zhang, X., \& Sauerborn, R. (2007). Willingness to pay for social health insurance among informal sector workers in Wuhan, China: a contingent valuation study. BMC Health Services Research, 7(1), 114.

Basarir, A., Sayili, M., \& Muhammad, S. (2009). Analyzing producers' willingness to pay for high quality irrigation water. Bulgarian Journal of Agricultural Science, 15(6), 566-573.

Bee, T. S., \& Selamat, J. (2010). Consumers ' perceptions, attitudes and willingness to pay towards food products with " no added Msg " labeling. International Journal of Marketing Studies, 2(1), 65-77.

Cameron, T. A., \& James, M. D. (1987). Efficient estimation methods for "closed-ended" contingent valuation surveys. The Review of Economics and Statistics, 269-276.

Carson, R.T., and Hanemann, W.M. (2005). Contingent valuation, in Maler, K.G., Vincent, J.R., ed., Handbook of Environmental Economics. Valuing Environmental changes. Amsterdam: 2:821-936.

Desvousges, W. H., Johnson, R., Dunford, R., Boyle, K., Hudson, S., \& Wilson, N. (1992). Measuring nonuse damages using contingent valuation: An experimental evaluation of accuracy (Vol. 1992). Research Triangle Park: Research Triangle Institute.

Dolgopolova, I., \& Teuber, R. (2016). Consumers' willingness-to-pay for healthy attributes in food products: a meta-analysis. In Agricultural \& applied economics association annual meeting.

Donaldson, C., Jones, A. M., Mapp, T. J., \& Olson, J. A. (1998). Limited dependent variables in willingness to pay studies: applications in health care. Applied Economics, 30(5), 667-677.

Fang, P. (2015). Evaluating consumer response to labels and packaging in the market for baby foods. Kilts booth marketing series, paper No. 1-047. Marketing Data Center at the Chicago Booth Kilts Center for Marketing.

Gil, J. M., \& Soler, F. (2006). Knowledge and willingness to pay for organic food in Spain: Evidence from experimental auctions. Acta Agriculturae Scand Section C, 3(3-4), 109-124.

Greene, W. H. (2005). Econometric analysis. New York: Pearson Education.

GSS. (2012). 2010 population and housing census: summary report of final results. A Publication of the Ghana Statistical Service.

Hanemann, W. M. (1989). Welfare evaluations in contingent valuation experiments with discrete response data: reply. American Journal of Agricultural Economics, 71(4), 1057-1061.

Kampman, E., Giovannucci, E., van't Veer, P., Rimm, E., Stampfer, M. J., Colditz, G. A., \& Willett, W. C. (1994). Calcium, vitamin D, dairy foods, and the occurrence of colorectal adenomas among men and women in two prospective studies. American Journal of Epidemiology, 139(1), 16-29.

Katchova, A. L., \& Miranda, M. J. (2004). Two-step econometric estimation of farm characteristics affecting marketing contract decisions. American Journal of Agricultural Economics, 86(1), 88-102.

Kumasi Metropolitan Assembly (KMA). (2013). Development plan Kumasi metropolitan area. Kumasi: Kumasi Metropolitan Assembly.

Kurth, A., Weaver, M., Lockhart, D., \& Bielinski, L. (2004). The benefit of health insurance coverage of contraceptives in a population-based sample. American Journal of Public Health, 94(8), 1330-1332.

Loureiro, M. L., \& McCluskey, J. J. (2000). Consumer preferences and willingness to pay for food labeling: A discussion of empirical studies. Journal of Food Distribution Research, 34(3), 95-102.

Mäler, K. G., \& Vincent, J. R. (Eds.). (2003). Handbook of environmental economics: valuing environmental changes (Vol. 2). Elsevier.

Mason, D. (2008). Tiger nuts (online). UK: National Vegetable Society Retrieved on the, 5, 12, 2016.

McFadden, D. (1994). Contingent valuation and social choice. American Journal of Agricultural Economics, 76(4), 689-708.

Meng, T., Florkowski, W. J., Sarpong, D. B., \& Chinnan, M. S. (2014). Consumer 's food shopping choice in Ghana: supermarket or traditional outlets? International Food and Agribusiness Management Review, 17, 107-129.

Miedzybrodzka, Z., Semper, J., Shackley, P., Abdalla, M., \& Donaldson, C. (1995). Stepwise or couple antenatal carrier screening for cystic fibrosis?: women's preferences and willingness to pay. Journal of Medical Genetics, 32(4), 282-283.

Moore, B. (2004). In B. Moore (Ed.), The Australian Oxford dictionary. Melbourne: Oxford University Press.

Mordi, J. I., Okafor, J. N. C., Ozumba, A. U., Solomon, H. M., \& Olatunji, O. (2006). Contaminants and defects in Nigerian tiger-nut varieties. Tropical Science, 46(3), 141-142. 
Noor, J., Siddiqi, W., and Muhammad, T. (2010). Estimation of willingness to pay for improvements in drinking water quality in Lahore: a case study of WASA, Lahore. Online at http://mpra.ub.uni-muenchen.de/53763/. MPRA Paper No. 53763, posted 19. February 2014 14:24 UTC

O'Brien, B., \& Viramontes, J. L. (1994). Willingness to pay: a valid and reliable measure of health state preference? Medical Decision Making, 14(3), 289-297.

Pascual, B., Maroto, J. V., López-Galarza, S., Sanbautista, A., \& Alagarda, J. (2000). Chufa (Cyperus esculentus L. var. sativus Boeck.): an unconventional crop. Studies related to applications and cultivation. Economic Botany, 54(4), 439-448.

Pascual-Seva, N., San Bautista, A., López-Galarza, S., Maroto, J. V., \& Pascual, B. (2016). Response of drip-irrigated chufa (Cyperus esculentus L. var. sativus Boeck.) to different planting configurations: Yield and irrigation water-use efficiency. Agricultural Water Management, 170, 140-147.

Plants, F. T. F. (1988). A resource book for promoting the exploitation and consumption of food plants in Arid, semi arid and Sub humid Lands of Eastern Africa. Food and nutrition paper, 4-2.

Reaves, D. W., Kramer, R. A., \& Holmes, T. P. (1999). Does question format matter? Valuing an endangered species. Environmental and Resource Economics, 14(3), 365-383.

Rheinländer, T., Olsen, M., Bakang, J. A., Takyi, H., Konradsen, F., \& Samuelsen, H. (2008). Keeping up appearances: perceptions of street food safety in urban Kumasi, Ghana. Journal of Urban Health, 85(6), 952-964.

Sanful, R. E. (2009). The use of tiger-nut (Cyperus esculentus), cow milk and their composite as substrates for yoghurt production. Pakistan Journal of Nutrition, 6, 755-758.

Shikhov, V. N., Velichko, V. V., Nesterenko, T. V., \& Tikhomirov, A. A. (2011). Ontogenetic approach to assessment of chufa response to culture conditions by the method of chlorophyll fluorescence induction. Russian Journal of Plant Physiology, 58(2), 359-363.

Straub, M. O., \& Thomassin, P. J. (2006). Product attributes and consumer willingness to pay for environmental management systems in agriculture: Using the choice modeling technique. Cell, 202, 459-8001.

Tetteh, J. P., \& Ofori, E. (1998). A baseline survey of tiger nut (Cyperus esculentus) production in the Kwahu South District of Ghana. Ghana Journal of Agricultural Science, 31(2), 211-216.

TTSL. (2005). Tiger nuts. Chufas. Souchet. Ermandeln. PoisSucrés: Tiger nuts Traders, S.L. Export. http://www.tigernuts.com/ product3.html/.

Ukwuru, M. U., \& Ogbodo, A. C. (2011). Effect of processing treatment on the quality of tigernut milk. Pakistan Journal of Nutrition, 10(1), 95-100.

Wiredu, A. N., Zeller, M., \& Diagne, A. (2015). What determines adoption of fertilizers among rice-producing households in northern Ghana. Quarterly Journal of International Agriculture, 54(3), 263-283.

Yahaya, I., Yamoah, F. A., \& Adams, F. (2015). Consumer motivation and willingness to pay for "safer" vegetables in Ghana. British Food Journal, 117(3), 1043-1065.

Yamane, T. (1967). Elementary sampling theory (Vol. 1, pp. 371-390). Englewood Cliffs: Prentice Inc.

Yasunaga, H., Ide, H., Imamura, T., \& Ohe, K. (2006). Willingness to pay for health care services in common cold, retinal detachment, and myocardiac infarction: an internet survey in Japan. BMC Health Services Research, 6(1), 12.

Yeboah, K. (2014). Tiger nuts: are they worth chewing? Graphic Ghana, Accra. Accessed on 8 July 2018. Available at https:// www.graphic.com.gh/features/features/tiger-nuts-are-they-worth-chewing.html

Zhang. (1996). Yellow nut-sedge as a fuel. Industrial Crops and Products, 5, 117-181.

\section{Submit your manuscript to a SpringerOpen ${ }^{\circ}$ journal and benefit from:}

- Convenient online submission

- Rigorous peer review

Open access: articles freely available online

- High visibility within the field

- Retaining the copyright to your article

Submit your next manuscript at $\boldsymbol{\nabla}$ springeropen.com 